\title{
Effects of calcium channel blockade on histamine induced bronchoconstriction in mild asthma
}

\author{
EH WALTERS, J BANKS, A FENNERTY, BH DAVIES \\ From the Asthma Unit, Sully Hospital, and Department of Thoracic Medicine, Llandough Hospital, Cardiff
}

ABSTRACT Inhalation histamine dose-response curves were constructed 15 minutes after inhalation of saline placebo or verapamil $(4 \mathrm{mg})$ for eight patients with mild atopic asthma in a double blind, random manner. No significant change in baseline specific airways conductance occurred after inhalation of verapamil, though there was a significant decrease in sensitivity to histamine (increase in threshold of response) $(p<0.01)$. There was, however, an associated significant increase $(p<0.01)$ in the slopes of the subsequent histamine dose-response curves.

Verapamil is a member of a group of drugs that have been termed calcium antagonists ${ }^{1}$ or, more specifically, calcium channel blockers. ${ }^{2}$ In a variety of tissues, including airways smooth muscle, these drugs act by inhibiting membrane potential dependent calcium influx from the extracellular fluid, which would stimulate excitation-contraction coupling and thus muscle contraction. ${ }^{3}$

Several groups of workers have observed a beneficial effect of calcium channel blockade in exercise induced bronchospasm. ${ }^{4-7}$ An inhibitory action of nifedipine on the bronchoconstrictor action of inhaled histamine has also been reported in mild asthma, ${ }^{8}$ but others have been unable to confirm such an effect for either nifedipine or verapamil. ${ }^{10}$ These studies used forced expiratory volume in one second $\left(\mathrm{FEV}_{1}\right)$ as the index of airways calibre. The use of $\mathrm{FEV}_{1}$ in pharmacological studies, however, has been questioned. ${ }^{11}$ Not only are relatively large doses of drug needed to elicit a response, but the deep inspiration and forced expiration needed for the manoeuvre may themselves modify that response.

In the study we describe, specific airways conductance (sGaw) has been used as a more sensitive measure of change in airways calibre for obtaining graded, cumulative inhaled histamine dose-response curves after inhalation of placebo and of verapamil. This has allowed us to obtain an estimate of the threshold of bronchoconstrictor response ("sensitiv-

Address for reprint requests: Dr EH Walters, Clo Asthma Research Unit, Sully Hospital, Penarth, South Glamorgan.

Accepted 16 April 1984 ity") of the airways and also the slope of the subsequent dose-response curve ("reactivity") 1213 with these different pharmacological regimens.

\section{Methods}

Eight subjects with mild atopic asthma (six of them female; mean age 24, range 19-34 years) took part in the study after informed consent and ethical approval had been obtained. None were smokers and none required regular medication. In each patient the disease was well documented and controlled by occasional inhalations of a $\beta$ adrenergic agonist drug only. On recruitment to the study all had an $\mathrm{FEV}_{1}$ greater than $70 \%$ of the predicted normal value.

The first part of the study was performed double blind and in random order. Subjects attended the laboratory at the same time of day on two separate occasions, at least three days apart, and avoided all medication for at least 12 hours before each part of the experimental procedure. After sitting quietly in the laboratory for 30 minutes a measurement of sGaw was made. This was repeated after five minutes and the mean of these values was taken as the baseline for that day. After measurement of sGaw, subjects inhaled completely $4 \mathrm{ml}$ of test solution from a Wright nebuliser driven by compressed air at $20 \mathrm{lb} / \mathrm{in}^{2}(137.9 \mathrm{kPa})$. The test solution consisted of either a mixture of verapamil and normal saline containing $1 \mathrm{mg}$ of vèrapamil per $\mathrm{ml}(4 \mathrm{mg}$ inhaled dose) or normal saline alone. The verapamil solution was colourless, odourless, and tasteless and experimental blindness was complete.

Inhalation of solution was completed within 15 minutes. sGaw was remeasured at five minute inter- 
Baseline specific airways conductance and sensitivity $\left(D_{20}\right)$ and reactivity (slope) to inhaled histamine after inhalation of placebo and of verapamil

\begin{tabular}{|c|c|c|c|c|c|c|}
\hline \multirow[b]{2}{*}{$\begin{array}{l}\text { Subject } \\
\text { No }\end{array}$} & \multicolumn{3}{|l|}{ Placebo } & \multicolumn{3}{|l|}{ Verapamil } \\
\hline & $\begin{array}{l}\text { Baseline sGaw } \\
\left(s^{-1} \mathrm{KPa}^{-1}\right)\end{array}$ & $\begin{array}{l}D_{20} \\
(m g / m l)\end{array}$ & $\begin{array}{l}\text { Slope } \\
\left(s^{-1} \mathrm{kPa}^{-1}\right)\end{array}$ & $\begin{array}{l}\text { Baseline sGaw } \\
\left(s^{-1} \mathrm{KPa}^{-1}\right)\end{array}$ & $\begin{array}{l}D_{20} \\
(m g / m l)\end{array}$ & $\begin{array}{l}\text { Slope } \\
\left(s^{-1} \mathrm{kPa}^{-1}\right)\end{array}$ \\
\hline $\begin{array}{l}1 \\
2 \\
3 \\
4 \\
5 \\
6 \\
7 \\
8 \\
\text { Mean }(\mathrm{n}=8) \\
\text { SD } \\
\text { SE }\end{array}$ & $\begin{array}{l}2.3 \\
2.0 \\
1.6 \\
2.0 \\
2.0 \\
2.2 \\
2.2 \\
1 \cdot 8 \\
2.01 \\
0.23 \\
0.08\end{array}$ & $\begin{array}{l}2.88 \\
0.06 \\
0.07 \\
0.09 \\
0.08 \\
2.47 \\
0.29 \\
0.23 \\
0.77(0.25) \\
1.18(4.80) \\
0.42\end{array}$ & $\begin{array}{l}-0.77 \\
-0.65 \\
-0.32 \\
-0.64 \\
-0.65 \\
-0.50 \\
-0.72 \\
-0.75 \\
-0.63 \\
0.15 \\
0.05\end{array}$ & $\begin{array}{l}2 \cdot 1 \\
2 \cdot 3 \\
1 \cdot 6 \\
2 \cdot 0 \\
2 \cdot 1 \\
2 \cdot 3 \\
2 \cdot 1 \\
1 \cdot 8 \\
2 \cdot 04 \\
0 \cdot 24 \\
0 \cdot 09\end{array}$ & $\begin{array}{l}9 \cdot 30 \\
0 \cdot 14 \\
2 \cdot 12 \\
0 \cdot 40 \\
0 \cdot 80 \\
19 \cdot 80 \\
0 \cdot 61 \\
1.21 \\
4 \cdot 30(1 \cdot 38) \\
6.95(5 \cdot 13) \\
2 \cdot 46\end{array}$ & $\begin{array}{r}-0.94 \\
-2.40 \\
-1.03 \\
-0.80 \\
-1.47 \\
-2.80 \\
-1.13 \\
-1.56 \\
-1.52 \\
0.72 \\
0.25\end{array}$ \\
\hline
\end{tabular}

Data derived from the regression line of the descending part of each log cumulative dose-response curve. Numbers in parentheses give the geometric means and standard deviations for $\log D_{20}$ values.

SD-standard deviation; SE-standard error.

vals for a further 15 minutes. The last of these values was taken as the baseline for construction of an inhaled histamine dose-response curve.

The concentrations of histamine diphosphate used ranged from $0 \cdot 1 \mathrm{mg} / \mathrm{ml}$ to $15 \mathrm{mg} / \mathrm{ml}(34.35 \mathrm{mg} / \mathrm{ml}$ cumulative) in approximately doubling cumulative concentrations via a Wright nebuliser. Doses were given at three minute intervals and each consisted of 10 tidal breaths standardised by a respiratory metronome set at 18 breaths per minute. sGaw was remeasured between one and a half and three minutes after each dose. The experiment was continued until a fall in sGaw of about $60 \%$ constriction had occurred. At the end of the experiment bronchoconstriction was rapidly reversed by inhalation of salbutamol $(400 \mu \mathrm{g})$ from a metered dose inaler.

sGaw was measured in a constant volume whole body plethysmograph. ${ }^{14}$ At each time point the last six of seven technically satisfactory readings were recorded. Resistance and volume angles were measured with the aid of an electronic resolver displayed on the oscilloscope screen, with the numerical values for the angles out of sight of the operator until the end of the measuring procedure. It was thus hoped to prevent subjective bias in measurement.

The regression line of the descending part of each log cumulative histamine dose-response curve was computed by least squares analysis, on the basis of values for a $15 \%$ or greater fall in SGaw. The concentration of histamine which would have caused a $20 \%$ fall in sGaw $\left(D_{20}\right)$ was calculated from this line and used as an index of airways sensitivity to histamine. The slope of the regression line was taken as the reactivity of the airways. Values of baseline sGaw, $\log D_{20}$, and slope were compared by means of Student's $t$ test for paired values.

A preliminary study had indicated that the dose of inhaled verapamil used caused no change in either resting pulse rate or blood pressure. Further measurement of these variables was not included in the above protocols.

\section{Results}

No subject experienced side effects after inhaling verapamil. There was no significant difference in baseline sGaw between control and verapamil study days (table). Inhalation of neither saline nor verapamil caused a significant change in sGaw over the 15 minute postinhalation observation period (ending about 30 minutes after the start of the drug inhalation).

Verapamil caused a significant decrease in sensitivity to inhaled histamine $(p<0.01)$, the mean value of $D_{20}$ increasing from $0.77 \mathrm{mg} / \mathrm{ml}$ after placebo to $4.30 \mathrm{mg} / \mathrm{ml}$ after verapamil. Once bronchoconstriction had occurred, however, the reactivity of the airways was significantly increased after verapamil, with an increase in the mean value of slope from $-0.63 \mathrm{~s}^{-1} \mathrm{kPa}^{-1}$ for control days to $-1.52 \mathrm{~s}^{-1} \mathrm{kPa}^{-1}$ after verapamil $(\mathrm{p}<0.01)$ (table, fig).

\section{Discussion}

Contractile agonists can bring about excitation-contraction coupling within smooth muscle cells in two ways, both of which cause an increase in calcium concentrations within the smooth muscle cell cytosol. One mechanism depends on cell membrane potential, mobilising calcium from the extracellular compartment, and is termed electromechanical coupling. The other mechanism, which is independent 


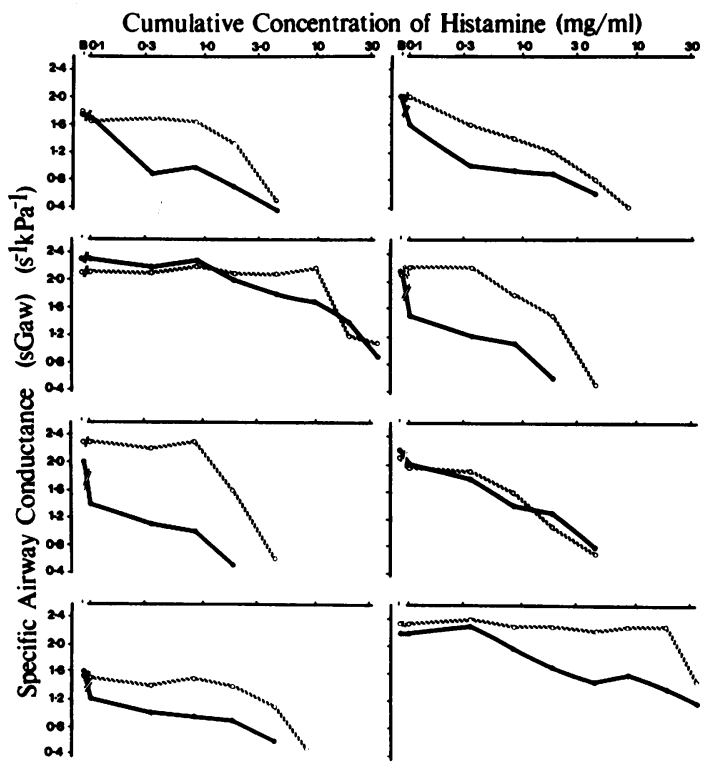

Individual cumulative concentration-response curves for histamine, in terms of sGaw, in all eight asthmatic patients, on two separate occasions. On one occasion the patient was premedicated with inhaled verapamil (................. ) and on the other occasion with saline as placebo

( Baseline values of sGaw on each occasion are also shown. Doses of histamine responses are plotted on a logarithmic scale.

of membrane potential, is much more dependent on intracellular calcium pools, and is termed pharmacomechanical coupling. Calcium channel blocking drugs inhibit only electromechanical coupling and do not affect pharmacomechanical coupling. ${ }^{3}$

Individual bronchoconstrictor agents vary in their dependence for activity on these two mechanisms for mobilising intracellular calcium ions, and it follows that the inhibitory effects of calcium channel blockers on airways smooth muscle contraction will vary according to which particular agonist is being studied. ${ }^{315}$ In addition an individual bronchoconstrictor agonist may not be completely uniform in its action. Thus in vitro acetylcholine has been shown to cause electromechanical coupling in canine airways smooth muscle only at low concentrations, while at higher drug concentrations pharmacomechanical coupling predominates in bringing about contraction. ${ }^{15} 16$ Only the lower concentrations of acetylcholine are inhibited by verapamil. ${ }^{16}$

In the present study verapamil was shown to have complex influences on the action of inhaled histamine in a group of patients with mild asthma. There was no overall effect on basal airways smooth muscle tone as reflected in sGaw, which confirms the findings of several other groups..$^{4-10}$

The sensitivity of the airways to inhaled histamine was significantly decreased, although most of these asthmatic subjects still remained more sensitive to histamine than normal ${ }^{17} 18$ even after calcium channel blockade. Reactivity of the airways to histamine, however, increased after verapamil inhalation, so that its beneficial effect seen at low histamine concentrations largely disappeared when the concentration of inhaled histamine was increased.

The overall effect of calcium channel blockade on histamine inhalation that we have demonstrated in asthmatic subjects is very similar to the effect described by Farley and Miles ${ }^{16}$ on acetylcholine induced airways smooth muscle contraction in vitro. The explanation may also be the same. Thus at low concentrations of inhaled histamine the bronchoconstrictor effect of histamine may be via electromechanical coupling within airways smooth muscle, and thus amenable to the inhibitory action of verapamil and nifedipine, while at high concentrations histamine may induce predominantly pharmacomechanical coupling, uninfluenced by calcium channel blockade. A recent report has indicated that at relatively high concentrations histamine does indeed induce predominantly pharmacomechanical coupling within airways smooth muscle. ${ }^{19}$

The variable effect of calcium channel blockade on bronchoconstrictor responses, dependent as they seem to be on the dose of agonist, may explain the conflicting results reported when $F E V_{1}$ alone has been used to monitor responses. Williams et al reported a small but significant decrease in responsiveness to inhaled histamine in terms of $\mathrm{PC}_{20 \mathrm{FEV}}$, although Patel ${ }^{910}$ was unable to confirm this. The beneficial effect at low concentrations of bronchoconstrictor agonist could well be missed by using this technique, which requires relatively large doses of drug to elicit the magnitude of change used for statistical purposes.

The inhibitory action of calcium channel blockers on exercise induced asthma $\mathrm{a}^{4-7}$ has been cited as evidence that exercise in susceptible subjects may cause degranulation of mast cells, another calcium dependent mechanism.9 Another explanation is, however, possible. Those asthmatics who are responsive to exercise also tend to show bronchoconstriction at the lowest concentrations of inhaled agonist drug, ${ }^{20}$ which presumably then operates by electromechanical coupling. Possibly during exercise these individuals respond to similarly small concentrations of released mediators operating in the same potential dependent way. Of interest in this context is the observation that the effectiveness of calcium channel blockade in exercise induced bronchospasm is most evident when the change in airways calibre is 
relatively small. ' This may reflect a concentration dependence of the underlying mediator action. The source of the mediators could, however, be either mast cells or nerve endings.

We are grateful to Mrs Carol Bevan for her contribution to the study and Mrs Joy Holmes for typing the manuscript.

\section{References}

${ }^{1}$ Middleton E. Anti-asthmatic drug therapy and calcium ions: review of pathogens and role of calcium.J Pharm Sci 1980;69:243-51.

${ }^{2}$ McFadden ER. Calcium-channel blocking agents and asthma. Ann Intern Med 1981;95:232-3.

${ }^{3}$ Coburn RF. The airway smooth muscle cell. Fed Proc 1977;36:2692-7.

${ }^{4}$ Cerrina J, Denjean A, Alexandre G, Lockhart A, Duroux $P$. Inhibition of exercise-induced asthma by a calcium antagonist, nifedipine. Am Rev Respir Dis 1981;123:156-60.

s Patel KR. Calcium antagonists in exercise induced asthma. Br Med J 1981;282:932-3.

6 Patel KR. The effect of calcium antagonist, nifedipine, in exercise induced asthma. Clin Allergy 1981;11:42932.

${ }^{7}$ Barnes PJ, Wilson NM, Brown MJ. A calcium antagonist, nifedipine, modifies exercise-induced asthma. Thorax 1981;36:726-30.

${ }^{8}$ Williams DO, Barnes PJ, Vickers HP, Rudolf M. Effect of nifedipine on bronchomotor tone and histamine reactivity in asthma. $\mathrm{Br}$ Med $J$ 1981;283:348.

9 Patel KR. The effect of verapamil on histamine and methacholine-induced bronchoconstriction. Clin Allergy 1981;11:441-7.

${ }^{10}$ Patel KR, Al-Shamma M. Effect of nifedipine on histamine reactivity in asthma. Br Med J 1982;284:1916.
"Orehek J. Airway response to inhaled bronchoconstrictor drugs: clinical measurement and standardization. In: Hargreave FE, ed. Airway reactivity. Mechanisms and clinical relevance. Hamilton, Ontario: McMaster University, 1980:201-9.

12 Orehek J, Gayrard P, Smith AP, Grimaud C, Charpin J. Airway response to carbachol in normal and asthmatic subjects: distinction between sensitivity and reactivity. Am Rev Respir Dis 1977;115:937-43.

${ }^{13}$ Chung KF, Morgan B, Snashall PD. Effects of pharmacological antagonists on the slope and position of histamine dose-response curves: importance of initial bronchial calibre. Clin Sci 1981;61:6P.

${ }^{14}$ Dubois AB, Botelho SY, Comroe JH. A new method for measuring airway resistance in man using a body plethysmograph: values in normal subjects and in patients with respiratory disease. J Clin Invest 1956;35:327-35.

15 Farley JM, Miles PR. Role of depolarisation in acetylcholine-induced contractions of dog trachealis muscle. J Pharmacol Exp Ther 1977;201:199-205.

${ }^{16}$ Farley JM, Miles PR. The source of calcium for acetylcholine-induced contractions of dog tracheal smooth muscle. J Pharmacol Exp Ther 1978;207:340-6.

${ }^{17}$ Walters EH. Prostaglandins and the control of airways responses to histamine in normal and asthmatic subjects. Thorax 1983;38:188-94.

${ }^{18}$ Walters EH. Effect of inhibition of prostaglandin synthesis on induced bronchial hyperresponsiveness. Thorax 1983;38:195-9.

${ }^{19}$ Cerrina J, Renier A, Floch A, Duroux P, Advenier G. Effects of $\mathrm{Ca}$ antagonists on guinea-pig tracheal contractions induced by various agents. Am Rev Respir Dis 1982;125:226, suppl.

${ }^{20}$ Anderton RC, Cuff MT, Frith PA, Cockcroft DW, Morse JLC, Jones NL, Hargreave FE. Bronchial responsiveness to inhaled histamine and exercise. $J$ Allergy Clin Immunol 1979;63:315-20. 